\title{
Conectando famílias de construções genéticas: testes de DNA na reunificação da família somali na Finlândia*
}

\begin{abstract}
Petri Hautaniemi*
Resumo

Os temas centrais desse artigo, reunificação familiar em geral $e$ teste de DNA em particular, surgiram a partir de uma pesquisa em andamento acerca de jovens da Somália na Finlândia. Desde 1996, realizo uma pesquisa etnográfica - em escolas, clubes de jovens, ruas e cafés - com jovens da Somália que chegaram à Finlândia por volta de 1994 e que freqüentam escolas finlandesas nos subúrbios de Helsinki. Meu interesse geral nesta pesquisa longitudinal era conhecer as experiências de passagem para a vida adulta em contextos altamente diferenciados, não apenas do ponto de vista do país anfitrião, mas também cultural $e$ transnacionalmente. O tema, testes de DNA, toca na questão central desta pesquisa de modo profundo. Aqui, crescer não é visto como uma simples questão biológica. É um processo social no qual as relações, como laços de parentesco, são constituídas, vivenciadas e contestadas. Essas relações são poderosas para a identificação individual e social. A testagem-DNA pode violar simbólica e fisicamente o processo social de identificações íntimas $e$ de integridade pessoal.
\end{abstract}

Palavras-chave: Parentesco, Identidade, Imigração, Reunificação Familiar, Testes de DNA.

\footnotetext{
" Recebido para publicação em maio de 2007, aceito em agosto de 2007 (Tradução: Ethon Fonseca; Revisão: Cláudia Fonseca).

** Antropóloga, professora da Universidade de Helsinki, Finlândia. petri.hautaniemi@helsinki.fi
} 
Conectando famílias de construções genéticas

Connecting Genes-Building Families:

DNA Testing in Somali Family Reunification in Finland

\begin{abstract}
The central themes of this article, family reunification in general, and DNA testing in particular, came to the fore during a research project about young Somalians in Finland. Since 1996, I have been conducting ethnographic research - in schools, youth clubs, streets and cafés - with youngsters from Somalia who arrived in Finland around 1994, and who attend Finnish schools in the suburbs of Helsinki. My general interest in this longitudinal study was to learn about the experiences of coming of age in highly dispersed settings, not only in the vein of a local host country, but also culturally and transnationally. Here, growing up is seen not as a simple biological question. It is a social process in which relationships such as kinship ties are constituted, experienced, and contested. These are powerful relations for individual and social identifications. DNA-testing may both symbolically and physically violate this social process of intimate identifications and personal integrity.
\end{abstract}

Key Words: Kinship, Identity, Immigration, Family Reunification, DNA Tests. 
Petri Hautaniemi

\section{Introdução}

Segundo a Lei de Imigração Finlandesa, um refugiado ou portador de permissão de residir na Finlândia possui o direito legal - ao menos oficialmente - de ter sua família reunida. Contudo, na esteira do rigor crescente das políticas de asilo na Europa, o significado cultural e autenticidade das relações familiares reivindicadas tornaram-se controversos. $\mathrm{O}$ cerne da controvérsia deriva dos diferentes modos com que autoridades finlandesas $e$ imigrantes da Somália compreendem quem é e quem não é um membro da família.

Tal como inscrita nas práticas jurídicas finlandesas, a idéia de família e laços de parentesco não espelha as próprias práticas familiares $e$ as maneiras das pessoas se relacionarem na vida cotidiana. As práticas de famílias finlandesas tradicionais, agrárias e luteranas, são continuamente desafiadas por novas formações familiares - parcerias homossexuais, divórcio, recasamento e práticas variadas através das novas tecnologias reprodutivas. Há uma tensão contínua entre as esferas públicas e privadas da lei, na medida em que refletem diferentes tendências para legitimar o significado de vínculos sangüíneos ou sociais. Contudo, apesar das recentes mudanças e dicotomias variáveis de natureza-ecultura no âmbito das práticas jurídicas e culturais de parentesco, tem havido um entendimento cultural relativamente uniforme da "casa" (household) como uma metáfora central para uma verdadeira família. Isso traz não apenas implicações econômicas, mas também tende a contribuir para a idéia de um âmbito física $e$ mentalmente construído que acompanha a unidade familiar básica: o lar. A casa também tende a reduzir o número dos membros da família, no máximo dois adultos ou cônjuges, gerando um número de crianças, descendentes (ou dependentes, através das crescentes adoções) de um deles ou de ambos. As famílias de três ou mais gerações tornaram-se raras. Casamentos poligâmicos são proibidos, independentemente das orientações sexuais. Dentro do sistema complexo de Estado, com impostos e 
Conectando famílias de construções genéticas

heranças extremamente regulados e estilos de vida moderna individualizada, a família e a casa são arenas definidas estritamente para o parentesco (relatedness) e a reprodução.

Porém, o que delimita as fronteiras da família no contexto da Somália é radicalmente diferente daquilo empregado na Finlândia ou no Ocidente em geral. Na Somália, e entre imigrantes somalianos na Finlândia, a família, definida em termos muito mais abrangentes, é parte de uma ampla rede de parentesco. A identidade familiar de uma pessoa não exclui moradias multigeracionais ou laços íntimos recíprocos entre muitos pais e filhos dependentes. Da mesma forma, a idéia física e mental do lar pode ter uma conotação diferente. Na Somália, pesquisadores estudando parentesco se interessaram pelo impacto das tradições nômades sobre um sistema forte de parentesco patrilinear (Lewis, 1965). Esse sistema regula a afiliação não apenas entre indivíduos, mas entre grupos de parentescos maiores chamados clãs. Comparado às tradições agrícolas, centradas no Estado, na Europa do Norte luterana, o significado da família e de redes complexas de parentesco é muito mais crucial na Somália. A família da Somália fornece o quadro para um sistema de bem estar muito diferente do sistema conduzido pelo Estado finlandês. As funções desses sistemas de bem-estar na Somália sofreram trágicas provações devido aos transtornos políticos e conseqüentes deslocamentos de massas no Chifre da África no final do século $\mathrm{XX}$. Laços de parentesco, próximos e distantes, foram ativados em amplas redes de confiança e reciprocidade, divergindo muito das práticas das famílias nucleares do Ocidente moderno.

Os diferentes modos das duas sociedades compreenderem o significado cultural do pertencimento à família trazem à tona temas sobre a autenticidade das alegadas relações familiares para propósitos de reunificação, ao menos, aos olhos das autoridades de imigração finlandesas. No que diz respeito aos oficiais finlandeses de imigração, a preocupação central é determinar quem está qualificado como um verdadeiro membro em termos do entendimento normativo finlandês das relações familiares. 
Nesse contexto, as autoridades finlandesas introduziram os testes de DNA como meio para determinar, cientificamente, os limites de pertencimento familiar. Entretanto, informações disponíveis indicam que o uso dessa biotecnologia não foi bem-sucedido na revelação tecnológica das relações familiares e de parentesco, tampouco na resolução de impasses migratórios. Nesse sentido, as autoridades adquiriram uma ferramenta importante para a construção de um sentido normativo das diferenças culturais de família e, ao mesmo tempo, tornaram essas diferenças irrelevantes.

O Diretório Finlandês de Imigração realiza testes de DNA quando a documentação de laços familiares, baseada em parentesco biológico é, ao seu ver, insuficiente. ${ }^{1}$ Um postulado é possibilitar o fornecimento de prova significativa do parentesco por meio de um teste de DNA. O Diretório de Imigração pode permitir um teste de DNA se não há documentação para comprovar identidade e/ou parentesco, ou se a documentação disponível não é confiável e se as entrevistas com membros da família certificam o parentesco biológico. O teste de DNA é pago pelos cofres do Estado e, em princípio, é voluntário, mas a rejeição do teste por parte do solicitante pode levar à negação do direito de reunificação familiar. O teste é realizado mediante consentimento por escrito da pessoa a ser testada, por livre vontade, baseando-se na informação recebida. Os resultados não são utilizados para qualquer outro propósito senão o de estabelecer a existência de laços familiares exigidos para a obtenção de permissão de residência, nos casos de solicitação pela pessoa testada (www.uvi.fi).

\footnotetext{
${ }^{1}$ Agentes da polícia, um trabalhador médico, um trabalhador social e outros servidores públicos do Ministério do Interior estão envolvidos na verificação de vínculos familiares. Além disso, o consulado finlandês, nas regiões de onde saem imigrantes, desempenha um papel importante no processo.
} 
Conectando famílias de construções genéticas

\section{Pano de fundo: o caso da Somália e reunificação da família}

Meu interesse original na reunificação familiar, em geral, $e$ testagem de DNA, em particular, se apóia em minha pesquisa em andamento acerca de jovens da Somália na Finlândia. Minha pesquisa etnográfica iniciou em 1996 quando, pela primeira vez, encontrei um grupo de jovens da Somália que haviam chegado à Finlândia por volta de 1994 e freqüentavam escolas finlandesas no subúrbio de Helsinki. A maior parte deles veio para a Finlândia com pouca idade e, na época em que os encontrei, já falavam finlandês fluentemente. Desde então, tenho andado com eles pelas escolas, clubes de jovens, ruas e cafés e, nesse processo, conheci aproximadamente 20 jovens rapazes que estão agora com 30 e poucos anos. Meu interesse geral nesta pesquisa longitudinal é conhecer as experiências de passagem para a vida adulta em contextos altamente diferenciados, não apenas do ponto de vista do país anfitrião, mas também cultural e transnacionalmente. O tema, testes de DNA, toca na questão central desta pesquisa de modo profundo. Crescer, afinal de contas, não é apenas uma questão biológica, mas um processo social no qual as relações, como laços de parentesco, são constituídas, vivenciadas $e$ contestadas. Essas relações são poderosas para a identificação individual e social (Toren, 2002). A testagem-DNA pode violar simbólica e fisicamente este processo social de identificações íntimas e integridade pessoal.

No início dos anos 1990, quando a situação na Somália eclodiu numa guerra civil cada vez mais violenta, a Finlândia recebeu sua primeira leva de pedidos de asilo da Somália. ${ }^{2}$ Nesta época, aproximadamente 3.000 pessoas chegaram da Somália e receberam visto de residência na Finlândia. Muitos destes refugiados vieram à Finlândia sozinhos e, posteriormente, com a

2 Durante os anos 90, em relação ao grande número de aplicações na Suécia (16.300), a Finlândia recebeu apenas um pequeno número de pedidos de asilo (3.170 ). Ver as estatísticas UNCHR 31.5.2002: Number of Asylum applications in 30 industrial countries 1992-2001. 
ajuda do processo de unificação familiar, puderam receber seus parentes na Finlândia. Boa parte dessa demanda na Finlândia era feita por crianças - oficialmente designadas como "menores desacompanhados" -, que chegaram no país com outras pessoas que não seus próprios pais. Entretanto, poucos de meus jovens amigos somalianos não possuíam parentes em Helsinki. A maioria deles tinha ao menos alguém com quem morar, geralmente uma tia ou um tio e suas famílias. Evidentemente, alguns também tinham seus próprios pais, mas, na maioria das vezes, apenas a mãe.

Servidores públicos da Finlândia estavam ocupados em resolver problemas como a falta de documentos de identidade. As pessoas que procuravam asilo recebiam um código pessoal finlandês baseado em entrevistas. Isso acabou mais tarde se tornando motivo de disputa. ${ }^{3}$ Alguns dos rapazes, ao requererem asilo, forneciam às autoridades nomes diversos de seus nomes originais. Neste caso, tendiam a dar um nome compatível com os dos parentes com os quais estavam morando. $\mathrm{O}$ momento $e$ o local de nascimento também eram freqüentemente ambíguos. Depois de alguns anos na Finlândia, alguns rapazes mudaram de idéia e solicitaram a reunificação familiar para trazer os seus "próprios" pais. Uma das razões para a mudança de procedimento, entre outras, estava na insatisfação de alguns deles com seus novos lares e queriam se mudar para um Lar de Crianças - um abrigo juvenil administrado pelo município. Alguns estavam simplesmente com saudades de suas mães $e$ se deprimiam com as notícias sobre as pobres condições de vida de suas famílias no Chifre africano. Na época, os meninos tinham cerca de 10 a 13 anos. Em alguns casos, os pais "oficiais" não

${ }^{3} \mathrm{O}$ código pessoal de identificação é tão evidente para a sociedade de bemestar social finlandesa e para a própria percepção dos cidadãos, que a sua existência raramente é questionada. O sistema não é muito flexível, menos ainda em casos de mudança. Todos os benefícios de bem-estar, emprego, direitos e obrigações em relação à sociedade são regulados pelo código pessoal. Normalmente, as pessoas levam um único código, do nascimento até a morte. 
Conectando famílias de construções genéticas

queriam mais ser responsáveis pelas crianças e entregaram uma ou duas às autoridades finlandesas. Em outros, as crianças da Somália foram enviadas para morar na África ou outros lugares na Europa.

Autoridades no Diretório da Imigração reagiram com políticas cada vez mais rigorosas. Tornou-se mais difícil receber membros da família na Finlândia através de reunificação $e$ as demandas, freqüentemente, recebiam respostas negativas. Isso causou (e ainda causa) confusão entre os garotos, mas também entre servidores públicos e indivíduos que lidavam no dia-a-dia com a integração de imigrantes. Por um lado, estes servidores viam a situação das crianças da Somália como alarmante, mas, por outro, não podiam fazer nada por elas. Sua consternação era ainda maior, na medida em que estavam teoricamente encarregados a implementar políticas sociais de cunho prático "em benefício das crianças". Após várias rodadas de discussão entre autoridades diversas, um novo projeto foi lançado: "um projeto piloto de testagem de DNA". Mais de 300 solicitantes de reunificação familiar foram convidados a fornecer voluntariamente amostras de sangue para comprovar a informação sobre alegados laços de parentesco. ${ }^{4}$ Os 300 solicitantes já tinham recebido decisões negativas.

Para a maioria dos que forneceram uma amostra de sangue, o teste de DNA propiciou uma decisão positiva. O Diretório de Imigração foi obrigado a mudar sua decisão, na medida em que os vínculos consangüíneos foram sendo averiguados. Contudo, por motivos desconhecidos, muitos requisitantes nunca fizeram os testes. Alguns, provavelmente, não realizaram os testes de DNA

\footnotetext{
${ }^{4}$ Nenhum dos rapazes que entrevistei estava envolvido no teste piloto. Seus pedidos aparentemente ficaram na fila. Lenta, mas seguramente, muitos deles receberam decisões positivas. Não acompanhei os processos com precisão, pois os meninos não se animavam a falar sobre a reunificação da família na presença de outros. Nos encontros privados, eles costumavam falar muito mais, mas também sempre pediam minha ajuda para acelerar os processos junto a diversas autoridades.
} 
porque sabiam que não possuíam vínculos consangüíneos com as pessoas que queriam patrocinar, enquanto outros talvez não soubessem o paradeiro de seus familiares.

\section{A Lei da Investigação de DNA}

No início de 2000, após o projeto-piloto, uma nova lei, aprovada na Finlândia, tornou possível às autoridades estatais usar os testes de DNA de forma mais regular para checar a autenticidade das relações familiares declaradas entre imigrantes, particularmente somalianos. A lei declarava que se o requerente de asilo não pudesse provar, de nenhum outro modo, a existência de laços "verdadeiros" de família, as autoridades poderiam exigir dele/dela uma prova com o auxílio do teste de DNA. Essa biotecnologia estreitava o significado de pertencimento familiar às pessoas relacionadas biologicamente em primeiro grau. Dois grupos de imigrantes - somalianos e kurdos do Iraque - foram particularmente mencionados na nova lei, mas os somalianos eram os principais destinatários da lei, pois freqüentemente não possuíam documentação para a prova dos "verdadeiros" laços familiares.

Entretanto, a definição biotecnológica do pertencimento familiar não averiguava o fato de que as relações de parentesco são mais complicadas do que uma simples e direta relação consangüínea "cientificamente comprovada". As histórias de vida dos garotos ilustram particularmente esse dilema, na medida em que, no âmbito cultural, são relacionadas entre eles de várias formas, e sua relação consangüínea é de significação variante $e$ contextual. Essa significação é, de fato, de conhecimento comum para antropólogos, embora historicamente contestada (ver Stone, 2001; Carsten, 2000; Schneider, 1986). Conseqüentemente, a lei levanta muitas questões relevantes não apenas para os solicitantes de asilo e refugiados oriundos da Somália, mas também para o Estado com interesses específicos no bem-estar de seus membros legais e cidadãos num contexto globalizado e transnacional. 
Conectando famílias de construções genéticas

Argumento que o próprio processo de tornar alguns laços de parentesco transparentes e legalmente mais válidos implica em fronteiras e categorias culturais e políticas, nas quais um Estado de bem-estar se reproduz no tempo, no espaço, $e$ as idéias não podem se sustentar sem um entendimento do significado dos vínculos de família a partir de perspectivas múltiplas e globais. $\mathrm{O}$ sangue e a família têm forte relevância simbólica na reprodução social na qual o estado também categoriza e arranja grupos de pessoas, sexos e idade na sua ordem hierárquica (Herzfeld, 1997). Por exemplo, na constituição finlandesa, a família é representada como "pedra angular" da sociedade. Contudo, a definição de uma família real, ou seu significado, é continuamente debatida e qualificada por advogados, políticos e diversos especialistas de ONGs. As políticas de bem-estar e migração freqüentemente sustentam essas restrições, na medida em que uma definição mais limitada de família e de parentesco torna esses conceitos mais "manejáveis", transformando-os em objetos mais fáceis de governar. Família, enquanto uma unidade central na sociedade, também é questão de valores e sentimentos, evocando emoções e agency entre pessoas.

Além disso, tornar o parentesco e os laços consangüíneos de família transparentes para propósitos de controle não apenas prioriza os atores do Estado para definir quem é e quem não é um refugiado legítimo, mas também pode revelar laços biológicos que não foram necessariamente articulados anteriormente, como a relação de parentesco. Através dos testes, é relativamente comum constatar que a relação genética não se correlacione com os vínculos sociais e psicológicos entre pai e filho, por exemplo. Uma questão importante é se a testagem de DNA e sua implementação, realmente, constituem laços de parentesco que, de outro modo, nunca chegariam a existir. Além disso, a longo prazo, as pessoas podem começar a reproduzir laços de sangue para gerir a mobilidade da família transnacionalmente.

Mohamed, um dos meninos que conheço desde 1996, falou de sua luta com as autoridades. Sua irmã e a filha esperavam a 
chegada do marido/pai do Chifre africano à Finlândia. Todos estavam envolvidos no procedimento de DNA, mas tiveram que esperar por mais um ano. A irmã de Mohamed ficou deprimida e ele estava simplesmente exausto ajudando-a dia e noite. Fiquei surpresa com o fato do pai nunca ter visitado a Finlândia, e que a irmã tinha morado lá por mais tempo do que a idade da filha me fizera supor. Percebi que eu estava considerando o tempo de concepção e comparando-o com a duração da separação do pai. Mohamed não entrou em detalhes, mas me deu a entender que sua irmã visitara o marido na África, engravidou e voltou à Finlândia. Depois disso, ela fez mais um pedido para reunificação familiar.

Essa história me levou a refletir sobre novas formas potenciais de lidar com o parentesco global e seus modos de reprodução, no qual, por exemplo, o esperma é traficado à distância para ajudar as pessoas a se movimentar de um lugar para o outro. Afinal de contas, a concepção não preestabelece que duas pessoas estejam co-presentes. Novas tecnologias de reprodução tornaram possível fazer bebês e novos seres humanos sem intercurso sexual entre homem e mulher. Também do ponto de vista das biopolíticas transnacionais, substâncias reprodutivas são bens crescentemente disputados (cf. Radin, 2001). Observando o vídeo promocional sobre testes de DNA, recentemente lançado pelas autoridades, vi quão cuidadosamente um servidor público do Diretório de Imigração empacotou amostras de sangue em Nairobi para enviá-las de volta à Finlândia, guardadas por um oficial de polícia. Perguntei-me se outras substâncias corporais, como esperma ou ovos, estariam no mesmo avião sem o conhecimento das autoridades. Conexões transnacionais podem operar de várias maneiras e assumir formas contra-producentes. Enquanto a governança transnacional das práticas de parentesco se desenvolve numa direção, paradoxalmente, as próprias ações reguladoras podem produzir novas práticas de parentesco. 
Conectando famílias de construções genéticas

\section{Os regimes de verdade}

A investigação de DNA consiste em três partes, a amostra de sangue, o teste de laboratório e o resultado. Entrevistei um perito forense numa das universidades locais que me ajudou a entender o processo de testagem de DNA. Ele me disse que o teste DNA de paternidade ajuda a chegar o mais próximo possível "da verdade", mas não $100 \%$. O teste de DNA responde uma pergunta simples com uma resposta simples: qual a probabilidade de que esta mulher seja mãe desta criança? Esta é, portanto, a questão legal, onde a probabilidade (normalmente $99,99 \%$ em caso positivo) é suficiente para o reconhecimento oficial de um laço biológico em primeiro grau.

Entrevistei também uma servidora pública no Diretório da Imigração, que funciona como um elo importante na rede dos trabalhos das autoridades envolvidas. Ela disse que os testes de DNA são a única maneira confiável de saber a "verdade" sobre membros da família, porque, por mais triste que possa ser, pessoas (buscando asilo) nem sempre "dizem" a verdade. Para ela, a principal meta na investigação de DNA é reunir a família "verdadeira" e que uma criança possa viver com "seus próprios pais". Contudo, ela acrescentou que as crianças sem laços biológicos também poderão se unir a seus pais se houver evidência de que elas viveram enquanto pais e filhos, mas não especificou o procedimento realizado nestes casos. Surpreendentemente, a própria relação sangüínea, por si só, não garante a entrada na Finlândia. É apenas uma evidência extra para a decisão final sobre a reunião familiar. Contudo, o vínculo de sangue pesa mais, na medida em que não existe outra "forma de saber a verdade".

Como antropóloga formada, esta servidora pública conhece a natureza dos sistemas de parentesco na Somália. Nas paredes de seu escritório se vêem mapas de regióes da Somália, pintados em 
diferentes cores, com nomes de clãs e sub-clãs. ${ }^{5}$ Cada requisitante, ela mostrou, tem uma ficha que inclui a história da família baseada numa entrevista. Na parte inferior da ficha ela desenha uma árvore genealógica para completar a informação. Segundo ela, esse procedimento é demorado e pode ser muito complicado, "até porque nem sempre é uma questão de relação pai-mãe-filho, mas também pode haver filhos vivos de outros casamentos $e$ outros parentes nas famílias". Ela me prova, então, quão difícil é o seu trabalho, mostrando a grande espessura de uma das fichas.

O processo tem diferentes etapas: após considerar o "caso", o servidor público pode solicitar evidência suplementar para constatar a existência de elos familiares, convidando o requisitante $e$ as pessoas relacionadas a irem à polícia para uma entrevista extra na Finlândia. Parentes na África devem ir à embaixada para uma entrevista semelhante na África, marcada em data e hora específicas. Inicialmente, o servidor público compara a informação "qualitativa" baseada nas entrevistas. Dependendo dos resultados, o requisitante é convidado a fornecer uma amostra de sangue. Em data marcada, o servidor público viaja para a África em companhia do oficial de polícia. O médico local, na África, toma amostras de sangue dos parentes e o servidor público, com a ajuda do policial e do pessoal na embaixada, realiza o trabalho de documentação. Eles retornam à Finlândia, onde o laboratório local examina as amostras de sangue. O livre consenso dos requisitantes é atestado pela sua assinatura ou impressões digitais. "Apenas para garantir", ela acrescenta, as autoridades finlandesas tiram as impressões digitais de cada demandante de asilo (muitos são analfabetos), incluindo as crianças. Nesse processo, uma questão relevante fica evidente: como podem assinar com uma impressão digital se não sabem ler o que estão assinando?. Também é importante saber que a polícia está elaborando um

${ }^{5}$ É interessante como o conhecimento antropológico de parentescos da Somália dos anos 1960 é usado mecanicamente neste contexto. Suponho que esta especialista se apóie, ao menos indiretamente, nos trabalhos de Lewis (1965). 
Conectando famílias de construções genéticas

arquivo pan-europeu baseado em impressões digitais de requerentes de asilo que entraram na união européia.

\section{As famílias e informação biológica}

Compreender relações familiares na intersecção da guerra civil e do exílio globalizado é um assunto complicado que desafia o antropólogo, tanto metodologicamente como conceitualmente. Essa complexidade conceitual e metodológica ocorre porque muitas famílias da Somália vivem em diásporas e formam um tipo de rede transnacional e aberta de relações. Não podemos falar de qualquer tipo de família estático ou delimitado neste contexto (Bryceson e Vuorela, 2002). Na verdade, o caso não é muito diferente no contexto cultural finlandês. Metade dos casamentos acaba em divórcio. Não é incomum a existência de famílias de casais em união consensual com crianças comuns e de crianças de uniões prévias. A adoção, freqüentemente de caráter transnacional, é também uma prática bem conhecida em muitas famílias da Finlândia. Novamente, na Somália, divórcios são comuns. Poligamia e adoção de crianças são comuns $e$, nas famílias, vivem muitas outras crianças além dos filhos biológicos (Helander, 1991).

Conseqüentemente, neste contexto comparativo, argumento que a preocupação das autoridades finlandesas em tornar laços biológicos transparentes está menos relacionada ao verdadeiro estilo de vida das famílias, e mais às idéias específicas sobre unidades sociais significativas na sociedade e sua vontade de controlá-las. Porém, isso não significa que os testes de DNA não teriam conseqüências nas famílias e entre seus membros. Pelo contrário, a informação genética construída através de biotecnologia moderna pode ter vários efeitos (ver Strathern, 1999). Primeiro, o teste de DNA pode produzir ou questionar informações significativas quanto à identidade pessoal. Segundo, também pode incidir nas redes de relacionamento e na noção de pertencimento a elas. Essa rede pode mudar como resultado de informação 
biológica. Terceiro, a relação genética ou sua falta pode subtrair relações enquanto se constroem novas. As relações nas famílias e entre indivíduos e suas famílias podem ser contestadas na medida em que nova informação, além de afetar o pertencimento pessoal, pode levantar questões sobre propriedade, herança e subsistência ou obrigações e autorizações.

$\mathrm{O}$ demandante de asilo não é testado sem seu consentimento informado. Porém, seu consentimento é relativo, na medida em que a recusa ao teste automaticamente conduz a uma decisão negativa de reunificação familiar por parte das autoridades. Numa declaração do Ministério da Justiça (OML 6.8.1999), a pessoa, no caso, é obrigada a tomar sua própria decisão quanto à participação no teste de DNA quando não há outro meio de constatar suas relações familiares. Contudo, sua "própria" decisão parece ambígua se levarmos em conta que a informação genética produzida afeta um conjunto maior de pessoas inter-relacionadas, e não apenas o demandante de asilo.

Aparentemente, a lei é criada em um contexto de discordância $e$, nesse sentido, pode ser analisada enquanto processo, procurando entender onde surge a discordância, como é controlada e em que fóruns se lida com ela (Moore, 1987). Assim, a lei de DNA pode ser tomada como uma disputa acerca de "quem é o verdadeiro membro da família". A lei enuncia, explicitamente, que "é necessário, no interesse da criança, que esta, através da reunificação familiar, chegue aos seus 'pais verdadeiros'".

No contexto histórico atual, onde os testes de DNA são realizados, há numerosos grupos e seres humanos pensantes, cuja presença pode contestar essa constituição atual de informação biológica. A disputa em torno de quem é o "verdadeiro" membro da família questiona a correlação entre parentesco genético e o interesse da criança. Essa relação é evocada e apresentada em diversas ocasiões (em debates finlandeses sobre a lei da nova 
Conectando famílias de construções genéticas

tecnologia reprodutiva e o projeto genoma humano ${ }^{6}$ ) como "fato cultural" (Franklin \& Ragone, 1998). Contudo, não sabemos realmente como aqueles que não possuem esta relação - mas ainda são parentes (cf. Howell, 2002) - a interpretam. Na Finlândia, crianças adotadas, "da guerra" (Segunda Guerra Mundial), de mães estupradas na guerra, frutos de inseminação artificial por doadores e, ainda, filhos crescendo em uniões não heterossexuais podem identificar seu relacionamento de forma mais complexa. Provavelmente, muitas outras pessoas também pensariam dessa forma. Nem sabemos ao certo quantos rejeitariam o recebimento deste tipo de informação genética. Quantos gostariam de não saber? Finalmente, quem pode escolher?

Essas perguntas são centrais na minha pesquisa sobre um grupo de jovens rapazes da Somália, vivendo na Finlândia. Argumentaria que para muitos deles a informação de que não descendem biologicamente de seu pai mudaria suas vidas. Em termos antropológicos, as comunidades da Somália ainda são fortemente patrilineares. Contudo, os efeitos potenciais da informação genética produzida pelos testes não têm gerado qualquer debate maior entre as autoridades envolvidas nos testes de DNA. Os efeitos e as conseqüências sociais são obscuros para todas elas. Os peritos e autoridades do Estado não podem antever e controlar o futuro social após terem produzido a informação. Eles podem, e de fato procuram, ser cuidadosos e também tentam controlar o direito do requisitante de asilo de conhecer o resultado do teste. A servidora pública no Diretório de Imigração disse, durante a entrevista, que o requisitante de asilo envolvido na investigação de DNA não necessariamente recebe os resultados do teste, mas apenas a decisão final sobre reunificação familiar. Somente com o auxílio de um advogado o requisitante de asilo pode conhecer o resultado do teste de DNA. Em muitos casos, as

${ }^{6}$ Para uma discussão inspirada na tecnologia moderna e sua história contemporânea dentro e fora da Finlândia, ver, também, Berglund (2003). 
autoridades podem conhecer o parentesco genético, enquanto quem busca asilo apenas o supõe.

Além da imprevisibilidade das conseqüências sociais para a informação ligada ao DNA, a implementação dessa forma de biotecnologia, neste e em outros contextos, pode afetar a vida social e cultural de várias maneiras. Testes de DNA trazem o potencial de uma nova e profunda mudança em nossa conceitualização de família, relações de gênero e parentalidade (Fonseca, 2002). As conseqüências podem ter um alcance muito maior do que o previsto. Mencionei como a lei de DNA, aliada à tecnologia relacionada, pode constituir novos laços de parentesco. O caso da irmã de Mohamed me serviu, então, de exemplo empírico.

\section{Laços contestados}

A nova lei de DNA tornou possível a muitos somalis receber suas famílias na Finlândia, o único caminho para provar que seus laços familiares são "de verdade". Seu sangue fala mais alto do que suas palavras. Até aqui, examinei o papel da informação biológica e sua autoridade no contexto das práticas de imigração finlandesas. Constatamos que a biologia não garante automaticamente a entrada no país. Servidores públicos também averiguam vínculos, entrevistando e comparando histórias de vida com o auxílio de árvores genealógicas para se certificar se os laços genéticos redundam ou não em laço familiar social. Essa verificação é significativa em casos de adoção ou guarda. A poligamia, proibida na Finlândia, também torna a situação complicada para autoridades. Nas famílias da Somália, não é incomum estar relacionado a diversas mães através das outras mulheres do pai. Segundo a servidora pública que entrevistei, nestes casos, não basta o vínculo biológico, os requisitantes devem mostrar ter vivido "sob o mesmo teto" por um período significativo de tempo. Ela continua, o pai, que tem quatro esposas e busca receber todos os seus filhos de todos os 
Conectando famílias de construções genéticas

casamentos na Finlândia, deve mostrar que ele viveu uma "vida verdadeiramente familiar" com todos estes filhos. Apesar disso, apenas uma esposa é aceitável no país por reunificação familiar na Finlândia.

O caso de DNA apresenta um bom exemplo de como os Estados estão longe de diminuírem seu poder nessa época de globalização. Refugiados são comumente vistos como uma ameaça às fronteiras nacionais. Diferentes tipos de política tentam governar a mobilidade de não-cidadãos e, através destas, os refugiados são classificados em categorias limiares, que não se encaixam na ordem nacional das coisas (Malkki, 1995:8). A ordem de parentesco e família é de interesse particular aqui, e os atos de governo realizados pelas autoridades podem ser interpretados como especializados desta ordem.

Esta ordem é parte da biopolítica global, onde, por via do corpo, subjetividades são incluídas ou excluídas, remetidas a espaços em mutação. Fassin (2001) chama isso de "outrificação biopolítica"; cada vez mais, a categorização legal de imigrantes na França é realizada em termos de saúde mental ou física e dos respectivos diagnósticos. Neste artigo, porém, eu também destacaria a idéia extremamente complexa entre relacionamento $e$ burocracias do sistema de bem-estar. Lei, parentesco e emoções estão numa relação construtiva um com respeito a outro. A própria lei é uma força crucial que modela o "ambiente emocional". A lei não apenas complica relações familiares, mas, de fato, estrutura poderes de emoção ao evocar "desejos $e$ estratégias que trabalham para contornar e subverter a lei, tanto quanto para a realização do seu propósito" (Yanagisako, 2000:53). Neste artigo, essa emoção e essa estratégia se apresentam como uma noção estruturante que pode estar entrelaçada na lei, na tecnologia e em suas implementações. 
Petri Hautaniemi

\section{Referências bibliográficas}

BERGLUND, E. Finland as Information Society: An anthropological critique. Suomen Antropologi 4, 2003.

BRYCESON, D. \& VUORELA, U. (eds.) Transnational Families in Europe: Global Networks and New Frontiers. London, Berg, 2002.

CARSTEN, J. (ed.) Cultures of Relatedness: New Approaches to the Study of Kinship. Cambridge, Cambridge University Press, 2000.

FASSIN, D. The Biopolitcs of Otherness: Undocumented Foreigners and Racial Discrimination in French Public Debate. Anthropology Today 17/1, 2001.

FONSECA, C. DNA, choice, and destiny in the contemporary Brazilian family. Paper presented in the $7^{\text {th }} E A S A$ conference, Copenhagen, 1417 August, 2002.

FRANKLIN, S \& RAGONÉ, H. (eds.) Reproducing Reproduction: Kinship, Power, and Technological Innovation. Philadelphia, University of Pennsylvania Press, 1998.

HeRzFeld, M. Anthropology and the Politics of Significance. Social Analysis 41(3), 1997.

HOWELL, Signe. Self-conscious kinship: Some contested values in Norwegian transnational adoption. In: FrankLIN, S.; MCKINNON, S. (eds.) Relative Values: Reconfiguring Kinship Studies. Durham, Duke University Press, 2002.

LEWIS, I.M. The Modern History of Somaliland, from Nation to State. London, Weidenfeld and Nicolson, 1965.

MALKKI, L. Purity and Exile: Violence, Memory, and National Cosmology Among Hutu Refugees in Tanzania. Chicago, The University of Chicago Press, 1995.

MOORE, S. F. Explaining the present: theoretical dilemmas in processual ethnography. American Ethnologist 14, 1987.

RADIN, J.M. Contested Commodities: The Trouble with Trade in Sex, Children, Body Parts, and Other Things. Cambridge, Harvard University Press, 2001. 